\title{
ARTIKELEN
}

\section{Het Cornelius Haga Lyceum in gevecht met de overheid*}

\author{
Miek Laemers
}

\section{$1 \quad$ Een moeilijke start}

Hoewel het Haga Lyceum vooral sedert 2019 veelvuldig in de belangstelling van de landelijke nieuwsmedia staat, is het nuttig om terug te kijken naar het moment waarop de plannen tot het stichten van deze islamitische school voor voortgezet onderwijs vorm kregen, en een blik te werpen op de ontstaansgeschiedenis van dit lyceum. ${ }^{1}$

In mei 2010 moest het Islamitisch College Amsterdam (ICA) in Amsterdam NieuwWest sluiten omdat het al jarenlang kampte met slechte inspectierapporten. Mede daardoor liep het aantal leerlingen zo ver terug dat de minister besloot de bekostiging te staken. De school vocht de beëindiging van de bekostiging tevergeefs aan bij de Afdeling bestuursrechtspraak van de Raad van State (ABRvS; ook: de Afdeling) ${ }^{2}$

In oktober 2010 deed de Stichting Islamitisch Onderwijs Amsterdam en Omstreken (SIO) een aanvraag voor een nieuwe islamitische school voor voortgezet onderwijs in Amsterdam. In het bestuur van SIO zaten enkele personen die ook bij het ICA werkten: de broers Soner en Son Tekin Atasoy waren de drijvende krachten achter de stichting van deze nieuwe school. De school kreeg in augustus 2011 toestemming van de minister om van start te gaan, ondanks bezwaren vanuit het gemeentebestuur. ${ }^{3}$ De stichting kon immers aantonen dat er genoeg belangstelling was en de school had een erkende religie als grondslag voor schoolstichting. De gemeente Amsterdam weigerde echter SIO een gebouw te geven, zodat van een

* Dit artikel bevat elementen uit de afscheidsrede van Miek Laemers als hoogleraar onderwijsrecht aan de Vrije Universiteit, 'Onderwijsrecht omdat ons onderwijs bijzonder is', onder meer gepubliceerd in het Nederlands Tijdschrift voor Onderwijsrecht en Onderwijsbeleid 2020/2, p. 66-78. Ook te lezen op: www.verus.nl/sites/www.verus.nl/files/documenten/afscheidsrede_miek_laemers_12-12-09. pdf.

1 Zie ook de Volkskrant 20 januari 2020, www.volkskrant.nl/nieuws-achtergrond/de-haga-saga-ditzijn-de-belangrijkste-gebeurtenissen-in-de-strijd-om-het-omstreden-islamitische-lyceum b9cdddb0/.

2 De Afdeling bestuursrechtspraak van de Raad van State heeft in zijn uitspraak van 26 mei 2010 (ECLI:NL:RVS:2010:BM6427) het besluit van de staatssecretaris van Onderwijs in stand gelaten om de bekostiging van ICA per 1 augustus 2010 stop te zetten. Het bestuur van ICA had middels een voorlopige voorziening om schorsing gevraagd. De raad oordeelde dat 'geen sprake is van een bijzonder geval' op grond waarvan de staatssecretaris voor ICA een uitzondering had moeten maken op de regel dat bekostiging van een school wordt stopgezet bij een te laag aantal leerlingen.

3 De bezwaren betroffen o.a. de nieuwe bestuurders, die immers ook in het slecht presterende bestuur van ICA actief geweest waren. 
echte start nog geen sprake kon zijn. ${ }^{4}$ De redenen die voor de weigering werden aangedragen, liepen uiteen, maar hadden als kernpunt het gebrek aan vertrouwen in de bestuurders. In 2014 was er een incident dat dit gebrek aan vertrouwen verder voedde: een bestuurslid van SIO betuigde zich op Facebook sympathisant van ISIS. De toenmalige Amsterdamse onderwijswethouder Kukenheim verklaarde dat een schoolbestuur dat zich niet uitdrukkelijk distantieert van een dergelijke uitspraak - zoals het geval was - volgens het gemeentebestuur geen verantwoordelijkheid kan dragen voor de leerlingen.

In 2016 spande SIO een rechtszaak aan tegen de gemeente Amsterdam voor de ABRvS. De gemeente had namelijk nog steeds niet voorzien in huisvesting voor de nieuw te starten school, onder meer omdat volgens het college door de school geen goede invulling zou worden gegeven aan artikel 17 van de Wet op het voortgezet onderwijs (WVO), waarin is bepaald dat het onderwijs er mede van uitgaat dat leerlingen opgroeien in een pluriforme samenleving en mede is gericht op het bevorderen van actief burgerschap en sociale integratie. ${ }^{5}$ Ook zou zich volgens het college strijd voordoen met het Internationaal Verdrag inzake de Rechten van het Kind (IVRK). De ABRvS stelde echter SIO in het gelijk en verplichtte de gemeente Amsterdam om vóór 1 augustus 2017 een pand beschikbaar te stellen aan de nieuwe islamitische scholengemeenschap. ${ }^{6}$ De Afdeling overwoog dat het college van B\&W niet de bevoegdheid heeft te beoordelen of de school voldoet aan de vereisten van artikel 17 WVO, zijnde een voorwaarde voor bekostiging van bijzonder onderwijs. Alleen de minister komt een oordeel toe over de goede uitvoering van artikel 17 WVO door de school, 'mede in het licht van het IVRK'.

Niet alleen de huisvesting vormde een struikelblok om daadwerkelijk van start te gaan. $\mathrm{Na}$ verloop van de geldigheid van het aanvankelijk, voor het Haga Lyceum gunstige bekostigingsbesluit in 2011 weigerde toenmalig staatssecretaris Sander Dekker in 2016 op een nieuwe aanvraag van SIO de bekostiging van de nieuwe islamitische middelbare school, omdat het inmiddels ook voor hem onduidelijk was - na de hiervoor gemelde extremistische uitspraken van het bestuurslid op Facebook - of de school de 'wettelijke burgerschapstaak' wel kon vervullen. Aldus sloot het ministerie de geldkraan nog voordat de school van start ging. In juli 2017 volg-

4 De stichting had op 12 september 2011 een eerste aanvraag ingediend voor een voorziening in de huisvesting voor deze school vanaf het schooljaar 2013/2014 door het schoolgebouw van het voormalige ICA aan de Jacob Geelstraat 38 te Amsterdam blijvend in gebruik te mogen nemen. Die aanvraag werd door de gemeente afgewezen. De ABRvS oordeelde dat de stichting uiterlijk op 1 augustus 2017 diende te beschikken over huisvesting voor 186 leerlingen. Aangezien het voormalige ICA duizend leerlingen kon herbergen, zou het toewijzen van een deel van die school dan wel van een andere huisvestingsplek ter keuze van de gemeente zijn.

5 Zie voor de grondslag van de gemeentelijke besluiten de uitspraak van ABRvS 21 oktober 2015, ECLI:NL:RVS:2015:3249.

6 ABRvS 21 oktober 2015, ECLI:NL:RVS:2015:3249.

7 ABRvS 21 oktober 2015, ECLI:NL:RVS:2015:3249, r.o. 5.1. 
de opnieuw een belangrijke uitspraak van de ABRvS, waarin de subsidieweigering door de staatssecretaris onterecht werd geoordeeld. ${ }^{8}$

Zeer tegen de zin van zowel de staatssecretaris als de gemeente Amsterdam kon het Cornelius Haga Lyceum na zes jaar van juridische strijd daadwerkelijk starten per 1 september $2017 .^{9}$

\section{Na de start}

In maart 2019 kwamen er berichten van de Algemene Inlichtingen- en Veiligheidsdienst (AIVD) naar buiten die een waarschuwing inhielden dat 'richtinggevende personen' op de school onder invloed zouden staan van 'salafistische aanjagers'. ${ }^{10}$ Ook zouden zij banden onderhouden met het aan Islamitische Staat gelieerde Kaukasus Emiraat. ${ }^{11}$ De 'richtinggevende personen' bleken directeur-bestuurder Soner Atasoy en zijn broer Son Tekin Atasoy, die als beleidsmedewerker op de school werkzaam was. ${ }^{12}$ Burgemeester Halsema van Amsterdam eiste dat het bestuur meteen zou opstappen, en de minister dreigde de bekostiging stop te zetten. ${ }^{13}$ Goede raad bleek duur voor de overheidsinstanties nu beide opties juridisch niet haalbaar waren. Vanuit het ministerie werd zelfs overwogen om de Wet bevordering integriteitsbeoordelingen door het openbaar bestuur (Wet BIBOB) in te zetten voor het Cornelius Haga Lyceum. ${ }^{14}$ Een BIBOB-toets inzetten om zo het Haga Lyceum uit te sluiten van onderwijsgeld vanwege het plegen van strafbare feiten is een ongebruikelijk wapen. Rechtsgeleerden reageerden in de dagbladen dat de inzet van de Wet BIBOB onwettig zou zijn en het dreigen met stopzetten van bekos-

8 ABRvS 26 juli 2017, ECLI:NL:RVS:2017:1979. Het beroep tegen het besluit van 22 juni 2017 (weigering van de staatssecretaris om aan SIO startbekostiging, aanvullende bekostiging en reguliere bekostiging voor de periode van 1 augustus 2017 tot 1 januari 2018 te verstrekken aan de Stichting Islamitisch Onderwijs) is gegrond. SIO mag een school voor mavo, havo en vwo oprichten in Amsterdam.

9 Geheel geruisloos ging de opening niet: er werd geprotesteerd door extreem-rechtse actievoerders, die vanaf het dak van de school de leus verspreidden: 'wie islam zaait, zal sharia oogsten'.

10 Het ging om een rapport van de AIVD met vertrouwelijke informatie. Die informatie is door de AIVD op verzoek van het kabinet naar buiten gebracht. Zie o.m. NRC Handelsblad 8 maart 2019.

11 'Richtinggevende personen' op het Cornelius Haga Lyceum verkeren volgens de AIVD in een radicale omgeving. Tussen 2009 en 2012 hadden zij banden met de terroristische organisatie Kaukasus Emiraat. Die beweging was in veel opzichten een voorloper van de latere Islamitische Staat (IS).

12 Als 'salafistische aanjagers' werden door de NCTV genoemd: de omstreden Britse shariageleerde Haitham al-Haddad, twee mannen van wie later bleek dat ze weinig met de school te maken hadden (imam Abdullah Özütürk en Fouad el Bouch, die preekt onder de naam Abu Hafs) en geschiedenisdocent Kasim Tekin. In een juridische procedure (Rb. Amsterdam 21 april 2021, ECLI:NL:RBDHA: 2021:3998) is duidelijk geworden dat de op het Haga Lyceum werkzame geschiedenisdocent Tekin ten onrechte is bestempeld als salafistische aanjager. Zie de Volkskrant 7 mei 2021, www.volkskrant. $\mathrm{nl}$ /nieuws-achtergrond/ten-onrechte-bestempeld-als-salafistische-aanjager-wie-iets-met-de-islamdoet-komt-ooit-op-een-verkeerd-lijstje b2bc98f3/.

13 Zie de berichtgeving in de media op en na 7 maart 2019, zoals op 14 maart 2019: https://nos.nl/ artikel/2275900-halsema-in-gesprek-met-ouders-haga-lyceum-zet-zelf-het-bestuur-af.

14 Zie o.m. de Volkskrant 5 april 2019. De Wet BIBOB is een (preventief) bestuursrechtelijk instrument. Als er een ernstig gevaar dreigt dat bijvoorbeeld een vergunning wordt misbruikt, kan de bevoegde overheidsinstantie de aanvraag weigeren of de afgegeven vergunning intrekken. Zo wordt voorkomen dat de overheid criminele activiteiten faciliteert. 
tiging evenzo. ${ }^{15}$ Stopzetting van bekostiging kan immers alleen als de Onderwijsinspectie vaststelt dat de kwaliteit van het onderwijs niet op orde is of als er te weinig leerlingen zijn. Atasoy vulde het vragenformulier in het kader van de Wet BIBOB dan ook niet in.

In april 2019 kwam nog een andere route in beeld om de school te kapittelen. Via NRC Handelsblad lekte informatie uit over een tweede ambtsbericht van de AIVD. ${ }^{16}$ Daarin stond dat bijna een derde van het schoolbudget in 2018 op was gegaan aan drie familieleden die werkzaam waren op het lyceum. Een van hen, directeur Soner Atasoy, verdiende meer dan de wettelijke salarisnorm voor schoolbestuurders. Het schoolbestuur stelde dat die fout al hersteld was en dat Atasoy een terugbetalingsregeling had getroffen met de school. Met de aanstelling van familieleden is als zodanig niets mis, stelde hij.

In mei 2019 lag er een conceptrapport van de Onderwijsinspectie, waaruit de advocaat van het Haga Lyceum tijdens een bijeenkomst citeerde. ${ }^{17}$ Hij haalde de inspectie aan waar die concludeert dat het salafisme geen rol speelt in het onderwijs aan het Cornelius Haga Lyceum. Ook zouden er geen aanwijzingen zijn dat de school met de rug naar de samenleving staat.

Een maand later bleek uit onderzoek van de Volkskrant dat de AIVD-informatie over de 'salafistische aanjagers' veel minder stellig was dan die begin maart naar buiten kwam. ${ }^{18}$ Zo hadden twee van de vier 'aanjagers' geen contact gehad met leerlingen binnen de school. Tijdens tientallen gesprekken met schoolleiding, docenten, medewerkers, ouders, vrijwilligers en externen vonden verslaggevers geen bewijzen van salafistische invloeden of antidemocratisch onderwijs. Deze uitkomst en de vele uitingen van kritiek betreffende de onwettige en niet-rechtsstatelijke acties van de landelijke en lokale overheid om het Haga Lyceum te stoppen, roepen natuurlijk vragen op naar de werkwijze van de AIVD in deze kwestie. In juli 2019 kondigde de Commissie van Toezicht op de Inlichtingen- en Veiligheidsdiensten (CTIVD) een onderzoek aan. In reactie daarop zei directeur-generaal Dick Schoof van de AIVD tegen de Volkskrant: 'We moeten constateren dat we de maatschappelijke dynamiek niet voldoende hebben beheerst, gecontained. ${ }^{19}$ En ook dat 'we niet voldoende gehoor hebben gegeven aan de gevoelens in de moslimgemeenschap'. Op de school zijn ook volgens de Onderwijsinspectie geen aanwijzingen gevonden voor salafistische invloeden en antidemocratisch onderwijs, maar de inspectie betoonde zich wel zeer kritisch over de financiën, het bestuur en de contacten met

15 Hoogleraar onderwijsrecht Paul Zoontjens sprak in de Volkskrant van 20 april 2019 van een 'buitengewoon kwalijke stap' van de overheid, en zelfs van een 'bestuurlijke guerrillatactiek'. www. volkskrant.nl/nieuws-achtergrond/bibob-toets-voor-omstreden-islamitische-school-bestuurlijkeguerrilla-tegen-haga-lyceum b605be81/.

16 NRC 22 april 2019; www.nrc.nl/nieuws/2019/04/22/eenderdebudget.

17 Advocaat Wouter Pors citeerde op 26 mei 2019 tijdens een bijeenkomst in het Amsterdamse debatcentrum De Balie uit het conceptrapport van de Onderwijsinspectie.

18 De Volkskrant juni 2019, www.volkskrant.nl/achter-de-schermen/2019-was-het-jaar-van-de-hagasaga-bij-ons-zat-ook-altijd-die-knagende-gedachte-misschien-worden-we-er-wel-ingeluisd bc314cb7/.

19 Zie ook Het Parool 3 juli 2019, www.parool.nl/nieuws/aivd-nu-zelf-onder-de-loep-om-hagalyceum b877dc5a/. 
mensen met extreme gedachten. ${ }^{20}$ De inspectie schreef van oordeel te zijn 'dat het onderhouden van en flirten met omstreden contacten en het niet ondubbelzinnig afstand nemen van contacten met personen waarvan de opvattingen over basiswaarden onduidelijk of discutabel zijn, ongewenst is' ${ }^{21}$

Minister Slob reageerde direct op de bevindingen van de Onderwijsinspectie over het bestuur: 'Deze bestuurders moeten echt uit de school verdwijnen', zei hij in een interview met de Volkskrant over zijn 'voorgenomen aanwijzing'. ${ }^{22}$ Nog geen week later berichtte de registeraccountant van het Haga Lyceum dat de financiën op orde zijn. ${ }^{23}$

Op 16 september 2019 gaf minister Slob op basis van het onderzoek van de inspectie en de Nationaal Coördinator Terrorismebestrijding en Veiligheid (NCTV) de school een definitieve aanwijzing: binnen twee weken moest het Haga Lyceum een voorstel doen voor een nieuwe interim-bestuurder, binnen vier weken moest deze bestuurder alle bevoegdheden overnemen. ${ }^{24}$ Gebeurt dat niet, dan draait de minister de geldkraan dicht. Per brief liet het Haga Lyceum aan de minister weten dat de beoogde (en door de minister goedgekeurde) interim-bestuurder pas over enkele weken kon worden geïnstalleerd. Er was een wijziging van de statuten nodig, omdat die stellen dat bestuurders 'belijdend moslim' moeten zijn en de beoogde interim-bestuurder was dat niet. Volgens de Volkskrant leek het bestuur zo tijd te willen winnen in de aanloop naar de cruciale rechtszaak van 11 november 2019, waarin het de inhoud van het inspectierapport zou aanvechten.

Een maand na de aanwijzing maakte minister Slob bekend de geldkraan van het Haga Lyceum per 1 december 2019 dicht te zullen draaien omdat de school nog geen interim-bestuurder had aangesteld. ${ }^{25} \mathrm{Om}$ te voorkomen dat de school 'voortijdig' zou worden gesloten, vroeg het schoolbestuur een voorlopige voorziening

20 Inspectie van het Onderwijs, 'Rapport Stichting Islamitisch Onderwijs en het Cornelius Haga Lyceum', 11 juli 2019, www.onderwijsinspectie.nl/documenten/rapporten/2019/07/11/onderzoekstichting-islamitisch-onderwijs-en-cornelius-haga-lyceum. Op 22 juni 2019 had het schoolbestuur in een kort geding openbaarmaking van het inspectierapport aangevochten, maar het gevorderde verbod werd afgewezen. De rechter oordeelde dat de inhoud van het rapport niet onrechtmatig was en het oordeel van de inspectie over het burgerschapsonderwijs niet in strijd met art. 17 WVO; Rb. Den Haag 11 juli 2019, ECLI:NL:RBDHA:2019:6860.

21 Inspectie van het Onderwijs 2019, p. 34.

22 De minister is bevoegd om een aanwijzing te geven indien er sprake is van 'wanbeheer' als gedefinieerd in art. 103g van de WVO. Wanbeheer is aan de orde als de kwaliteit van het onderwijs niet voldoende is gewaarborgd en het financiële beheer niet op pijl is binnen een onderwijsinstelling. Zie voor berichtgeving over het voornemen van de minister tot het geven van een aanwijzing onder meer de Volkskrant 11 juli 2019, www.volkskrant.nl/nieuws-achtergrond/zeer-kritisch-rapportover-haga-lyceum-openbaar-minister-slob-hekelt-bestuur be627767/.

23 Trouw 18 juli 2019. De volgende kanttekening wordt in Trouw gemaakt: 'Financieel wanbeheer hoeft namelijk niet te resulteren in een afkeurende accountantsverklaring, mits het jaarverslag maar een getrouw beeld geeft', www.trouw.nl/nieuws/haga-lyceum-heeft-financien-op-orde-zegt-deaccountant b79c494b/.

24 Art. 103g WVO regelt dat een aanwijzing - bestaande uit maatregelen die de rechtspersoon moet nemen - gegeven kan worden bij 'wanbeleid' van één of meer bestuurders.

25 Besluit minister Slob d.d. 15 oktober 2019 (201907613/1/A2): aangekondigd aan SIO dat de bekostiging van het CHL te Amsterdam met ingang van 1 december 2019 geheel (100\%) wordt ingehouden, tenzij SIO voor 12.00 uur op 17 oktober 2019 heeft voldaan aan de voorwaarden van de bij besluit van 16 september 2019 op grond van art. 103g WVO gegeven aanwijzing. 
aan bij de Afdeling bestuursrechtspraak van de Raad van State. ${ }^{26}$ Voordat het 1 december was, nam de Afdeling een gunstige beslissing voor het Haga Lyceum: de bekostiging mocht niet worden gestopt per 1 december 2019, omdat minister Slob zich bij het stopzetten van de bekostiging niet aan zijn eigen beleidsregels had gehouden. ${ }^{27}$

Vermeldenswaard is dat ongeveer ten tijde van laatstgenoemde uitspraak van de Afdeling de CTIVD kwam met de uitkomst van haar onderzoek: de veiligheidsdienst AIVD heeft onrechtmatig en onzorgvuldig gehandeld bij het uitbrengen van twee ambtsberichten over het Haga Lyceum. ${ }^{28}$

Naast de procedures over de bekostiging liepen er nog twee procedures: een kort geding in hoger beroep dat het Haga Lyceum aanspande tegen de Onderwijsinspectie, en een bodemprocedure van het bestuur van het Haga Lyceum tegen de aanwijzing van Slob. De civiele rechter in Den Haag deed op 24 december 2019 uitspraak in de zaak tegen de Onderwijsinspectie. Het Haga Lyceum vorderde de intrekking van het inspectierapport en een bevel om dat rapport te verwijderen van de diverse websites waarop het inmiddels was gepubliceerd. De school hoopte dat de rechter het rapport naar de prullenbak zou verwijzen en daarmee het fundament onder de aanwijzing vandaan zou slaan. Dat gebeurde niet: in hoger beroep liet het hof zich over de al dan niet onrechtmatigheid van het rapport niet uit. ${ }^{29}$ Het hof wees de vordering af omdat het Haga Lyceum daarbij geen belang of spoedeisend belang meer had: het rapport was immers al bekendgemaakt en op het moment van het beroep, halverwege het schooljaar 2019-2020, zou het inspectierapport geen invloed meer hebben op de schoolkeuze van ouders voor dat jaar. Van een leegloop op school na het verschijnen van het rapport was ook niet gebleken, integendeel, het aantal leerlingen was juist toegenomen. Het hof stelde vast dat de vordering van het Haga Lyceum vooral leek te zijn ingesteld om de onrechtmatigheid van het rapport vastgesteld te krijgen met het oog op de bestuursrechtelijke procedure over de aanwijzing van de minister. Een kort geding is daar niet voor bedoeld. Een kort geding is alleen bedoeld voor een ordemaatregel totdat in zo'n procedure uitspraak is gedaan en niet om die procedure te beïnvloeden, aldus het hof.

De rechtbank in Amsterdam boog zich over de kwestie of minister Slob de school terecht een aanwijzing gaf om het schoolbestuur te vervangen. Het verlossende antwoord kwam voor het Haga Lyceum op 20 januari 2020: minister Slob had nooit een aanwijzing mogen geven nu het door de rechtbank vastgestelde wanbeheer aanzienlijk minder omvattend en minder ernstig was dan de verwijten die de minister aan SIO had gemaakt. Slob stelde te hoge eisen aan het schoolbestuur als het

26 Tegen de dreigende stopzetting van de bekostiging wegens het niet voldoen aan de aanwijzing.

27 ABRvS 22 november 2019, ECLI:NL:RVS:2019:3949. De minister heeft zelf een beleidsregel vastgesteld voor het inhouden van de bekostiging van scholen. Die regel houdt in dat de bekostiging alleen wordt stopgezet als deze eerst voor $15 \%$ is opgeschort, na drie maanden voor $15 \%$ en na weer drie maanden voor $30 \%$ is ingehouden, én het bestuur dan nog altijd niet aan de wettelijke voorschriften voldoet. In het geval van het CHL heeft de minister meteen $100 \%$ inhouding aangekondigd. CTIVD, Toezichtsrapport, de gegevensverstrekking van de AIVD over het Cornelius Haga Lyceum; CTIVD nr. 67, vastgesteld op 20 november 2019; zie www.ctivd.nl > actueel > nieuws > 2019/12/06. Trouw 6 december 2019, www.trouw.nl/nieuws/haga-lyceum-heeft-financien-op-orde-zegt-deaccountant b79c494b/.

29 Gerechtshof Den Haag 24 december 2019, ECLI:NL:GHDHA:2019:3446. 
ging om het bevorderen van actief burgerschap en sociale integratie, oordeelde de rechtbank. ${ }^{30}$ Ook hoefde het schoolbestuur niet openlijk afstand te nemen van personen met een omstreden gedachtegoed, vonniste de rechter, omdat dit binnen de vrijheid van onderwijs valt. Bovendien was het volgens de rechtbank niet vast te stellen dat de personen waarvan vermoed werd dat ze leerlingen ongewenst zouden beïnvloeden, dit ook daadwerkelijk gedaan hadden. Minister Slob kondigde aan in hoger beroep te zullen gaan. ${ }^{31} \mathrm{Hij}$ zei op Twitter dat de wetgeving nu onvoldoende basis biedt voor een aanwijzing zoals hij die beoogde en hij meldde dat er inmiddels een nieuw wetsvoorstel voor burgerschapsonderwijs bij Tweede Kamer ligt. ${ }^{32}$ In hetzelfde bericht liet minister Slob weten in hoger beroep te gaan omdat het belangrijk is te weten wat hij wel mag 'in het belang van de leerlingen'.

\section{Directeur/bestuurder Atasoy door eigen bestuur aangeklaagd}

Medio 2020 spitsten de ontwikkelingen zich toe op het functioneren van Soner Atasoy binnen het Haga Lyceum. In mei 2020 werd hij geschorst en op 2 juni 2020 op staande voet ontslagen door de nieuw aangestelde bestuursvoorzitter van de Stichting Islamitisch Onderwijs, Mohammed Laamimach. Atasoy zou een 'angstbewind' voeren en hij zou de Onderwijsinspectie hebben afgeluisterd. ${ }^{33}$ Beide beschuldigingen werden ontkend door Atasoy. Op 10 juni 2020 deed de rechter uitspraak in een kort geding: Atasoy en de secretaris moesten vertrekken. ${ }^{34} \mathrm{Zij}$ vochten hun schorsingen en ontslagen aan. Op 7 augustus 2020 bepaalde de rechtbank dat Atasoy's ontslag onrechtmatig was en dat hij recht had op doorbetaling van zijn salaris. Vanwege de verstoorde werkrelatie en een gebrek aan draagvlak hoefde de school hem echter niet toe te laten op de werkvloer. Atasoy wilde dat via de rechter alsnog afdwingen. De rechter liet zijn ontslag echter in stand in zijn uitspraak van 12 november 2020. ${ }^{35}$ De kantonrechter achtte het ontslag gerechtvaardigd omdat Atasoy na te zijn geschorst het bestuur geen toegang gaf tot de bankrekeningen van de school. ${ }^{36}$ Daardoor ontstonden ernstige problemen, met

30 Rb. Amsterdam 20 januari 2020, ECLI:NL:RBAMS:2020:226.

31 Ik beschik niet over informatie of hoger beroep inderdaad is ingesteld. Onderwijsjuristen gaven hem weinig kans van slagen bij de Afdeling bestuursrechtspraak van de Raad van State. Zie bijv. M. Laemers, 'Dikastocratie in het onderwijs?', NTOR 2020-1, p. 3-5; R. van Schoonhoven in de Volkskrant 20 januari 2020.

32 https://twitter.com/arieslob/status/1219250214961369088?ref_src=twsrc\%5Etfw\%7Ctwcamp\% 5Etweetembed\%7Ctwterm\%5E1219250214961369088\%7Ctwgr\%5E\%7Ctwcon\%5Es1_\&ref_ url=https://www.ad.nl/binnenland/brministerslob-in-beroep-tegen-uitspraak-over-wegsturenbestuur-haga-lyceum-bra98aa986/.

33 B. Soetenhorst, Het Parool 12 oktober 2020: 'Een tiran', 'een manipulator die geen tegenstand duldt, niets van onderwijs weet en overal complotten ontwaart', dit zijn enkele diskwalificaties van Atasoy in het rapport van een recherchebureau, opgesteld in opdracht van het huidige schoolbestuur. Daarin vertellen dertien medewerkers - het merendeel anonieme docenten - en een ouder over de angstcultuur onder Atasoy, die zelf alle beschuldigingen ontkent. www.parool.nl/amsterdam/ personeel-haga-lyceum-ex-directeur-gaf-opdracht-tot-afluisteren bb4354a7/.

34 Rb. Amsterdam 10 juni 2020; ECLI:NL:RBAMS:2020:2891.

35 Rb. Amsterdam 12 november 2020, ECLI:NL:RBAMS:2020:5412.

36 Er speelde ook nog een kort geding waarin Atasoy opkwam tegen het loonbeslag. Op 14 oktober 2020 sprak de rechter uit Atasoy's verzoek tot opheffing daarvan niet te honoreren. 
name rond de betaling van salarissen aan het personeel. De rechtbank vond dit Atasoy ernstig aan te rekenen. ${ }^{37}$

Onder de kop 'Laatste stuiptrekkingen van Atasoy?' berichtte Het Parool over de spanningen op het Haga Lyceum, die hoog oplaaiden in de aanloop naar het hoger beroep waarmee oud-directeur Soner Atasoy hoopte via de rechter terug te keren op de school. ${ }^{38}$ Incidenten waren elkaar in rap tempo opgevolgd, maar een rustiger vaarwater voor het Haga Lyceum leek in zicht. ${ }^{39}$

\section{Een beroerde start, tegenwerking van de overheid en toch groei van aantal leerlingen}

De inmiddels breed uitgemeten kwesties rond het Cornelius Haga Lyceum vormen een zeer in het oog springende illustratie van hoe het mis kan gaan in de relatie tussen overheid (lokaal, centraal, inspectie) en schoolbestuur. ${ }^{40}$ De bestuurders van het Haga Lyceum hebben de aantijgingen van antidemocratisch onderwijs en salafistische invloeden op de school altijd ontkend, en ook de Onderwijsinspectie vond daarvoor geen signalen. Wel toonde de inspectie zich in een vernietigend rapport kritisch over de financiën, het burgerschapsonderwijs en de contacten van de bestuurders met mensen met extreem gedachtegoed. Ook dit rapport gaf weer aanleiding tot procedures in de ingewikkelde juridische strijd die het Haga Lyceum en het ministerie van Onderwijs al jaren voeren over het voortbestaan van de school. ${ }^{41}$ Het bericht in de media dat volgens de CTIVD de AIVD buiten zijn boekje was gegaan, maakte de afkeuring van de tegenstanders van de school wellicht wat minder scherp. ${ }^{42}$ Intussen was er wel al veel negatieve berichtgeving over het Haga Lyceum verschenen en was de publieke opinie gevoed met angstscenario's over het ontstaan van 'parallelle samenlevingen' door (de oprichting van) islamitische scholen. In eigen kring leek het vertrouwen van ouders en leerlingen goeddeels overeind te

37 B. Soetenhorst, Het Parool 12 november 2020.

38 Zo werd het Haga Lyceum op 30 november 2020 beklad met diverse leuzen aangetroffen. Zie B. Soetenhorst, Het Parool 8 december 2020, www.parool.nl/amsterdam/stemmingmakerij-op-hethaga-lyceum-zijn-dit-de-laatste-stuiptrekkingen-van-atasoy bcb5dd3a/.

39 Na het gereedkomen van deze bijdrage werd de uitspraak in hoger beroep bekend: het hof oordeelde dat oud-directeur en -bestuurder Soner Atasoy en ex-bestuurssecretaris Sadrettin Karadag geen recht hebbenop een rentree op de islamitische school in Nieuw-West. Zie bericht d.d. 2 maart 2021 op www.rechtspraak.nl/Organisatie-en-contact/Organisatie/Gerechtshoven/Gerechtshof-Amsterdam/ Nieuws/Paginas/Ontslagbesluiten-bestuurslid-en-directeur-Haga-Lyceum-blijven-in-stand.

40 Er zijn nog meer 'grote' voorbeelden: Amarantis (2012), ROC Leiden (2015) en VMBO Maastricht (2018).

41 Niet alle rechtszaken konden in deze bijdrage worden vermeld. Zo had SIO nog een zaak bij de Raad van State die ging over aanvullende bekostiging (op basis van art. 85a WVO). SIO had aanvulling gevraagd voor meer docenten op het Haga Lyceum. Volgens SIO is deze aanvullende bekostiging nodig omdat bij de bekostiging is uitgegaan van het leerlingaantal op teldatum 1 oktober 2018, te weten 175, terwijl het leerlingaantal op 1 augustus 2019 zal zijn gestegen naar 360 en daarom meer docenten moeten worden aangetrokken. Volgens SIO besliste de minister daar niet snel genoeg op. De ABRvS heeft - ook op 22 november 2019 - in deze zaak uitspraak gedaan: het beroep van SIO is niet-ontvankelijk, omdat de minister nog niet te laat is met zijn beslissing over de aanvullende bekostiging.

42 De AIVD zou onzorgvuldig en onrechtmatig te werk zijn gegaan. Zie o.a. www.ad.nl/binnenland/ onderzoek-aivd-opereerde-onrechtmatig-bij-haga-lyceum abf43a4fc/. 
blijven. De website van het Haga Lyceum berichtte in de loop van 2020 zelfs over de uitbreiding van het schoolgebouw vanwege het toenemende aantal leerlingen: na de zomer van 2020 zou worden gestart met 140 nieuwe leerlingen, wat het totale leerlingenaantal op 440 zou brengen. ${ }^{43}$

Eerder betoogde ik dat wij kunnen leren van de Haga-kwestie dat een bejegening vanuit de overheid c.q. de Onderwijsinspectie die gebaseerd is op wantrouwen, uiteindelijk zal leiden tot minder bereidheid van het schoolbestuur om commitment te betonen aan de geldende regels, omdat de school zich onrechtvaardig behandeld voelt. ${ }^{44}$ Daarnaast zijn er interessante rechtsstatelijke kwesties voor het voetlicht gekomen, zoals hoeveel vrijheid biedt de grondwettelijke vrijheid van onderwijs, maakt de overheid zich tegenover islamitische scholen schuldig aan bestuurlijke overkill, en zijn ideologische uitwassen te repareren met regels over burgerschapsonderwijs? Deze drie vragen komen hierna kort aan de orde.

\section{Onderwijsvrijheid ${ }^{45}$}

Wanneer de samenleving een school vanwege zijn ideologie niet accepteert, wordt als oplossing vaak naar voren gebracht om de vrijheid van onderwijs in artikel 23 van de Grondwet $(\mathrm{Gw})$ te wijzigen of zelfs af te schaffen. ${ }^{46}$ Artikel $23 \mathrm{Gw}$ maakt het immers mogelijk dat scholen gesticht kunnen worden op basis van een godsdienst of levensovertuiging en dat schoolbesturen de inrichting van het onderwijs (mede) bepalen op basis van die grondslag. De overheid bekostigt dat onderwijs zolang de school aan de wettelijke eisen voldoet.

Door de onderwijsvrijheid van artikel $23 \mathrm{Gw}$ heeft de overheid weinig mogelijkheden om de stichting van een school tegen te houden: wie een school wil oprichten en genoeg potentiële leerlingen heeft, kan in principe van start. Volgens de nieuwe regels voor schoolstichting is het zelfs niet nodig om - zoals voorheen wel het geval

43 Bericht van 24 juli 2020, https://corneliushagalyceum.nl/uitbreiding-cornelius-haga-lyceum-gestart/.

44 E. van Wijk \& F. Six, De diversiteit van het willen. Een onderzoek naar de dynamiek van motivaties achter regelnaleving, Den Haag: Boom Lemma uitgevers 2014. In dit boek wordt onder meer verkend wat de bijdrage kan zijn van Goal Framing Theory (GFT) in het beantwoorden van vragen rond die motivatie.

45 Zie voor uitvoerige beschouwingen over onderwijsvrijheid D. Mentink, B.P. Vermeulen \& P.J.J. Zoontjens, 'Commentaar op artikel 23 van de Grondwet', in: E.M.H. Hirsch Ballin \& G. Leenknegt (red.), Artikelsgewijs commentaar op de Grondwet (webeditie 2020), www.Nederlandrechtsstaat.nl.

46 Zie bijv. Den Boef in zijn bijdrage in NRC Handelsblad 15 juni 2013. Hij stelt dat sprake is van een inbreuk op het zelfbeschikkingsrecht en isolatie van jonge kinderen op streng religieuze scholen. Bovendien zou religie geen rol meer spelen bij schoolkeuze. Ook politieke partijen hebben plannen om het artikel over onderwijsvrijheid te herzien. De VVD wil regelen dat art. 23 niet meer strijdig mag zijn met art. 1 van de Grondwet, het gelijkheidsbeginsel. De PvdA wil het artikel aanpassen om gelijke kansen voor leerlingen mogelijk te maken. PvdA en D66 willen scholen dwingen elk kind te accepteren - ook als die een andere levensovertuiging heeft dan de school. 
was - uit te gaan van een erkende richting. ${ }^{47} \mathrm{Als}$ compensatie hiervoor vindt er wel vooraf een kwaliteitstoetsing door de Onderwijsinspectie plaats en - onder meer een toetsing van de rechtspersoon die als bevoegd gezag zal optreden. De stichtingsvrijheid brengt met zich dat ouders nu en in de nabije toekomst een school kunnen kiezen die past bij hun overtuiging en opvoeding. ${ }^{48}$ Een belangrijke vraag is hoever die overtuiging mag gaan. Kunnen ouders bijvoorbeeld een fascistische of streng orthodoxe school stichten? In de toekomst zal moeten blijken of de kwaliteitstoetsing voorafgaand aan schoolstichting, met onder meer eisen ten aanzien van burgerschapsonderwijs en een veto voor schoolbestuurders die eerder een zeer zwakke school bestuurden, voldoende waarborgen biedt voor het tegengaan van scholen met uitgangspunten die niet in overeenstemming zijn met de beginselen van de democratische rechtsstaat of deze zelfs ondermijnen. ${ }^{49}$

\section{$6 \quad$ Bestuurlijke overkill?}

Mede ingegeven door de ervaren onmacht om effectief op te treden in situaties als bij het Haga Lyceum willen de bewindslieden van het ministerie van Onderwijs, Cultuur en Onderwijs (de ministers Slob en Van Engelshoven) het sanctie-instrumentarium in verband met het niet voldoen aan burgerschapseisen uitbreiden. In maart 2020 werd daartoe een voorontwerp van de Wet uitbreiding bestuurlijk handhavingsinstrumentarium voor internetconsultatie aangeboden. ${ }^{50}$ Als grond voor een aanwijzing van de minister zal in de toekomst wellicht gaan gelden: 'het in ernstige mate of langdurig tekortschieten' in de naleving van de wettelijke bepalingen die gaan over de burgerschapsopdracht en de sociale veiligheid. Ook wordt

47 Het gaat om de Wet Meer ruimte voor nieuwe scholen (Stb. 2020, 160), die per 1 november 2020 voor het voortgezet onderwijs en per 1 februari 2021 voor het primair onderwijs in werking treedt. Doelstelling van de wet is het mogelijk maken dat scholen die aantoonbaar op voldoende belangstelling van ouders en leerlingen kunnen rekenen, meer dan thans het geval is ook daadwerkelijk voor bekostiging in aanmerking kunnen komen. In de nieuwe wet wordt het begrip 'richting' als bepalende factor in de scholenplanning losgelaten. In plaats van de huidige, op de godsdienstige of levensbeschouwelijke grondslag (richting) van scholen gebaseerde indirecte meting wordt een systeem voorgesteld waarin rechtstreeks bij de ouders naar de belangstelling voor een nieuwe school wordt gevraagd. Daartoe kan gebruik worden gemaakt van ouderverklaringen of van een marktonderzoek. Daarnaast geldt dat een toets vooraf wordt uitgevoerd om na te gaan of voldaan wordt aan een aantal kwaliteitseisen waaraan een nieuwe school moet voldoen om voor bekostiging in aanmerking te komen.

48 Dit is in lijn met de internationale verdragsregels inzake het recht op onderwijs, zoals art. 2 EP bij het EVRM.

49 Voor een kritische beschouwing van de nieuwe regels rond schoolstichting zie M. Laemers \& P. Zoontjens, Magnificently unprepared for the long littleness of life? (Preadvies voor de Nederlandse Vereniging voor Onderwijsrecht 2016), Den Haag: Sdu Uitgevers 2016, p. 11-57. De in de nieuwe wet opgenomen kwaliteitstoetsing vooraf biedt op zichzelf geen afdoende waarborg tegen 'minder goede' initiatieven tot schoolstichting. De auteurs uiten hun ongerustheid over het aspect van politiek in het Nederlands onderwijs, nu 'ons onderwijsstelsel onvoldoende middelen heeft om zich te verweren tegen politiek-ideologische stellingnamen en tegenstellingen van buitenlandse herkomst, die op onvermoede plaatsen in het land propaganda en strijd toelaten in de klas' (p. 36).

50 Als doel van de wet is geformuleerd: 'De minister meer mogelijkheden te geven om in te grijpen wanneer het bevoegd gezag of raad van toezicht tekort schiet en hij zijn verantwoordelijkheid die volgt uit artikel 23 van de Grondwet niet in voldoende mate waar kan maken.' 
in een spoedaanwijzing voorzien, die gegeven mag worden voordat definitief is komen vast te staan dat er daadwerkelijk sprake is van wanbeheer. Een redelijk vermoeden daarvan is voldoende, maar wel geldt als een van de eisen dat de Onderwijsinspectie heeft vastgesteld dat een deugdelijkheidseis is overtreden. De tijd zal leren of de Tweede en Eerste Kamer meegaan in een daad van wetgeving die voornamelijk ingegeven lijkt door het Haga-incident.

\section{Regels over burgerschapsonderwijs}

De aanwijzing van de minister aan het Haga Lyceum werd door de rechtbank vernietigd onder meer omdat de aangevoerde gronden voor die aanwijzing ondeugdelijk of onvoldoende zwaarwegend waren. Een schoolbestuur heeft immers de vrijheid om onderwijs in burgerschap op eigen wijze in te vullen, zolang maar aan die wettelijke doelstelling gewerkt wordt. Met de huidige regels over burgerschapsonderwijs kan de minister dus niet ingrijpen in scholen waar in ideologisch opzicht een onwenselijke koers wordt gevaren. Een voorstel tot aanscherping van de regels is daarom eind 2019 ingediend. ${ }^{51}$ Op 17 november 2020 is het wetsvoorstel Verduidelijking van de burgerschapsopdracht aan scholen in het funderend onderwijs aangenomen door de Tweede Kamer. Bij burgerschap staat het (leren) functioneren in de democratische rechtsstaat centraal en met dit wetsvoorstel wordt meer helderheid geboden over de algemene burgerschapsdoelstelling van het onderwijs en de uitgangspunten die daarbij gelden. De burgerschapsopdracht krijgt een meer verplichtend karakter en er worden bouwstenen ontwikkeld die de specifieke kennis en vaardigheden van leerlingen beschrijven. ${ }^{52}$ Tevens is voorzien in een zorgplicht voor het bevoegd gezag ten aanzien van de schoolcultuur. In de betreffende artikelen van de onderwijswetten (art. 8 Wet op het primair onderwijs, art. 11 Wet op de expertisecentra en art. 17 Wet op het voortgezet onderwijs) wordt vastgelegd dat in de scholen actief burgerschap en sociale cohesie op doelgerichte en samenhangende wijze moeten worden bevorderd, waarbij het onderwijs zich in ieder geval herkenbaar richt op 'de ontwikkeling van respect voor en kennis van de basiswaarden van de democratische rechtsstaat en de mensenrechten en het bijbrengen van de sociale en maatschappelijke competenties die leerlingen in staat stellen om deel uit te maken van en bij te dragen aan de samenleving'. ${ }^{53}$ Hoewel de regering stelt dat scholen ruimte houden om zelf inhoud en vorm te geven aan de burgerschapsopdracht vanuit hun eigen godsdienst of levensovertuiging, wordt die ruimte tegelijkertijd begrensd omdat de overheid een grondwettelijke verantwoordelijkheid heeft voor de kwaliteit van het onderwijs op stelselniveau en om ervoor te zorgen dat het onderwijs publieke belangen dient. Hoewel de gekozen formuleringen in de memorie van toelichting erg hinten naar de situatie bij het Haga Lyceum,

51 Kamerstukken II 2019/20, 35352, nr. 1-3.

52 Zie over dit wetsvoorstel J. van den Brink, 'Het Wetsvoorstel burgerschapsopdracht', Tijdschrift voor Religie, Recht en Beleid 2020-1, p. 8-13; N. van Steensel, 'De Grondwet als basis voor het goede samenleven? Waarom de Grondwet onvoldoende houvast biedt voor de burgerschapsopdracht in het onderwijs', Tijdschrift voor Religie, Recht en Beleid 2021-1, p. 6-22. 
waar het in de ogen van de overheid juist ontbrak aan de beschreven eisen, is het de vraag of met het aannemen van deze wet een schoolcultuur gebaseerd op de eigen (islamitische) grondslag - zo nodig - omgebogen kan worden in de gewenste zin.

\section{Tot slot}

In mijn afscheidsrede heb ik laten zien dat er soms bij de overheid sprake is van ongenoegen over of zelfs angst voor het bijzondere, voor het anders zijn, van scholen. Het is onmiskenbaar zo dat katholieke en protestantse scholen de strijd om erkenning al meer dan honderd jaar geleden hebben gewonnen en dat islamitische scholen, althans die voor voortgezet onderwijs, nog een weg te gaan lijken te hebben. ${ }^{54}$ Er zijn ruim vijftig islamitische basisscholen, maar het Avicenna College in Rotterdam is nu nog de enige islamitische middelbare school in Nederland naast het Haga Lyceum. ${ }^{55}$ Alle tien aanvragen voor nieuwe islamitische middelbare scholen zijn in 2019 afgewezen. ${ }^{56}$

Het overheidscredo van noodzakelijke integratie en sociale cohesie kan een bedreiging vormen voor (streng) religieuze scholen. Dat geldt evenzeer voor streng orthodox-christelijke scholen als voor scholen op basis van de nog niet lang in Nederland gewortelde religies of stromingen. ${ }^{57}$ Tegelijkertijd lijkt het onverstandig om hard op te treden tegen niet-traditionele scholen als de overheid werkelijk polarisatie in de samenleving wil tegengaan. In het geval van het Haga Lyceum bestond het bijzonder zijn niet alleen in het islamitisch zijn, maar vooral in de vermeende invloed van salafistisch gedachtegoed, met als complicerende factor het niet altijd gewaardeerde optreden van de directeur/bestuurder. Het gaat met andere woorden niet alleen om onderwijs-juridische kwesties, maar ook om het tegengaan van radicalisering in de brede samenleving. Het lijkt erop dat de overheid in de Haga-kwestie het onderwijs-juridisch beleidsinstrumentarium heeft gebruikt om een probleem aan te pakken dat het onderwijs overstijgt.

In de ogen van sommigen heeft het optreden van de overheid alles te maken met de heersende afkeer van islamitisch onderwijs. ${ }^{58}$ De Haga-casus laat echter zien dat de overheid ervan uitging dat daar meer aan de hand was. Voor mij staat het bestaansrecht van islamitische scholen of scholen van minderheden niet ter discussie, maar datzelfde geldt voor de pogingen om via het winnen van vertrouwen, het vergroten van tolerantie waar het gaat om verschillende levensstijlen, culturen en

54 Het Cornelius Haga Lyceum meldt op zijn website dat er voorafgaand aan zijn oprichting een 'strijd gewoed heeft die gelijkenissen heeft met de Schoolstrijd van 1917', https://corneliushagalyceum. nl/onderwijs/schoolplan/.

55 Onlangs bleek dat er ruimte is voor een islamitische middelbare school in Den Haag: minister Slob heeft een aanvraag van stichting Sivor goedgekeurd. De school kan na de zomer van 2021 van start. www.volkskrant.nl/nieuws-achtergrond/toch-ruimte-voor-islamitische-middelbare-school-in-denhaag bc2e687b/; 1 mei 2020.

56 Dat ging overigens in alle gevallen omdat de vereiste leerlingaantallen niet gehaald werden. NOS 9 juli 2019, https://nos.nl/artikel/2292691-alle-aanvragen-voor-nieuwe-islamitische-middelbarescholen-afgewezen.html.

57 Denk bijv. aan de in november 2020 ontstane commotie rond het vragen door reformatorische scholen van ouderverklaringen die een afwijzing van homoseksualiteit inhouden.

58 Vgl. Tweede Kamerlid Azerkan (Denk) in de Volkskrant 25 januari 2020. 
talen, en desnoods met behulp van onderwijswetten, te bereiken dat de rechtsstaat ondermijnende invloeden uit het onderwijs geweerd worden en gezamenlijk gedeelde waarden geleerd worden. 